\title{
RESSILABIFICAÇÃO DO RÓTICO E FRONTEIRAS PROSÓDICAS NO SUL DO BRASIL
}

\author{
RHOTIC RESYLLABIFICATION AND PROSODIC BOUNDARIES \\ IN THE SOUTH OF BRAZIL
}

\author{
Carolina Ribeiro Serra | Lattes | carolserraufrj@gmail.com \\ Universidade Federal do Rio de Janeiro \\ Mário Gomes Alves | Lattes | mariogomesalves@gmail.com \\ Universidade Federal do Rio de Janeiro $\mid \mathrm{CNPq}$
}

Resumo: Este artigo focaliza o processo variável de ressilabificação do $[\mathrm{r}]$ em contexto de coda silábica externa diante de vogal em palavra subsequente (calo[r, $\mathrm{r}, \mathrm{I}, \mathrm{h}]$ infernal $\sim$ calo[Ø] infernal $\sim$ calo[rĩ]fernal) e sua relação com as fronteiras dos constituintes prosódicos no português falado na região Sul do Brasil. São utilizadas amostras de fala de 12 indivíduos nascidos em Curitiba (4), Florianópolis (4) e Porto Alegre (4), estratificadas por sexo - masculino e feminino, e idade - 18 a 30 anos e 50 a 65 anos, todos com nível superior completo (https://alib.ufba.br/) O aporte teórico-metodológico adotado é o da Sociolinguística Quantitativa e o da Teoria da Hierarquia Prosódica. Foram contabilizados 1.136 dados contendo o rótico no contexto em questão, 159 em não-verbos e 977 em verbos. A análise variacionista, de forma geral, apontou: 1) a classe morfológica do vocábulo - não-verbos; 2 ) a dimensão do vocábulo que contém o $R$ - uma sílaba; 3 ) a qualidade das vogais dos núcleos silábicos - [+rec]; e 4) o tipo de fronteira prosódica - palavra prosódica, como variáveis favorecedoras da regra de ressilabificação do rótico.

Palavras-chave: Róticos; Ressilabificação; Fronteira prosódica; ALiB; Região Sul do Brasil.

Abstract: This paper focuses on the variable process of R-resyllabification, which occurs when the rhotic is in external final coda and is followed by a vowel of subsequent word (calo[r, $, \mathrm{l}, \mathrm{I}, \mathrm{h}]$ infernal $\sim$ calo[Ø] infernal $\sim$ calo[rĩ]fernal "infernal heat"), and the relation of the process to prosodic constituent boundaries in the South of Brazil. The corpus consists of speech samples from 12 graduate students, born in Curitiba (4), Florianópolis (4) and Porto Alegre (4), who were grouped according to sex - male and female, and age - 18 to 30 and 50 to 65 (https://alib.ufba.br/). The theoretical and methodologi- 
cal frameworks of this study include Quantitative Sociolinguistics and the Theory of Prosodic Hierarchy. A total of 1,136 words were analyzed: 159 non-verbs and 977 verbs. The multivariate analysis shows that the rothic resyllabification rule is favoured by: 1) the morphological class of the word - non-verbs; 2) the length of the word which carries the $R$ - 1 syllable; 3 ) the type of vowel in the syllabic nucleus - [+back]; and 4) the type of prosodic boundary - prosodic word.

Keywords: Rhotics; Resyllabification; Prosodic boundary; ALiB; South of Brazil.

\section{INTRODUÇÃO}

Este artigo inspira-se em estudos anteriores que buscam averiguar o encaixamento da estrutura segmental na estrutura prosódica, com o entendimento de que texto e melodia, segmentos e suprassegmentos estão intimamente relacionados na cadeia da fala. Não é recente a busca de evidências de que a estrutura prosódica, nomeadamente as fronteiras de constituintes prosódicos, impactará, de alguma forma, a ocorrência de fenômenos de sândi externo, na medida em que esses constituintes podem atuar como locus para a aplicação, a inibição ou mesmo o bloqueio de processos fonológicos variados.

O livro clássico de Nespor e Vogel (2007[1986]), Prosodic Phonology, propõe uma teoria prosódica que prevê que a representação mental da fala está dividida em constituintes hierarquicamente organizados - os constituintes ou domínios prosódicos - e fornece exemplos de processos fonológicos em diversas línguas que servirão de comprovação para a existência desses constituintes. No que diz respeito ao português do Brasil, uma quantidade de estudos filiaram-se à chamada Teoria da Hierarquia Prosódica na busca dessas evidências segmentais para a estrutura prosódica, dentre os quais podemos mencionar Bisol (1996, 2002), Tenani (2002, 2003, 2004) e, mais recentemente, Marcato (2013), Callou e Serra (2012) e Serra e Callou (2013, 2015).

No que se refere mais especificamente aos róticos, interessa-nos a abordagem de ressilabificação de Tenani $(2002,2003)$ - batizada pela autora de tapping -, a de Marcato (2013) e o tratamento dado por Callou e Serra (2012) e Serra e Callou (2013, 2015) ao processo variável de apagamento do $R$. Os pontos de contato entre esses estudos e a presente pesquisa são a descrição do processo de ressilabificação do rótico em coda externa relativamente ao tipo de fronteira prosódica em que se encontra o segmento, por um lado, e a observação sociolinguística da regra variável de realização dos róticos, por outro.

Neste artigo, aliamos então um modelo para estudo da variação e da mudança lin- 
guística, a Sociolinguística Variacionista Laboviana (LABOV, 1994), a uma teoria fonológica de gramática, a Teoria da Hierarquia Prosódica (NESPOR;VOGEL, 2007[1986]), na busca de mais uma explicação para a regra variável de ressilabificação do rótico. Mais especificamente, este artigo focaliza o processo de ressilabificação do [r] em contexto de coda silábica externa diante de vogal inicial de palavra subsequente (calo[r, $\mathrm{r}, \cdot, \mathrm{h}]$ infernal $\sim$ calo[Ø] infernal $\sim$ calo[rĩ]fernal), e sua relação com as fronteiras dos constituintes prosódicos: palavra prosódica $(\mathrm{Pw})$, sintagma fonológico ( $\varphi$ ou $\mathrm{PhP}$ ) e sintagma entoacional (IP) no português falado na região Sul do Brasil (Exemplos 1, 2 e 3, a seguir).

(1) Pw - É sinistra, deve se[ro]rrível. (Informante 1 - Curitiba)

(2) $\mathrm{PhP}$ - ...eu acho que professo[re] a melhor das profissões. (Informante 4 Florianópolis)

(3) IP - Sim, porque quando tu tira o braço do luga[ra]qui é clavícula. (Informante 1 - Porto Alegre)

Como se pode verificar, a ressilabificação do rótico é um processo de reestruturação silábica que envolve a passagem de uma consoante em coda final de palavra à onset da sílaba da palavra subsequente, iniciada por vogal, que resulta na formação de sílaba $\mathrm{CV}(\mathrm{C})$. Como veremos na seção 4, a partir dos resultados de Santana (2017), os falares da região Sul apresentam uma relativa diversidade de variantes para a realização do rótico em coda externa (retroflexa, tepe, fricativas velar e glotal) , sendo possível identificar a aplicação do processo pela passagem dessas consoantes róticas a tepe [r], na produção, para o preenchimento do onset silábico, e pela impossibilidade de pausa entre os vocábulos em questão.

Levando em conta que pesquisas recentes apontam uma diferenciação bastante marcada entre índices de cancelamento do rótico entre verbos e não- verbos nas capitais do Sul do Brasil (CARDOSO et al., 2014; SANTANA, 2017), pretendemos verificar ainda se também o processo de ressilabificação é sensível à classe morfológica do vocábulo. A análise variacionista leva em conta, entretanto, outras nove variáveis linguísticas e sociais que permitirão a observação dos fatores relevantes à aplicação da regra variável, além das variáveis independentes classe morfológica do vocábulo e tipo de fronteira prosódica, como veremos na seção 3 .

Além desta seção introdutória, o presente artigo conta com as seguintes seções: 2) Os róticos e a estrutura prosódica; 3) Aporte teórico-metodológico e materiais; 4) Antes 
de mais nada: o apagamento do $R$ no Sul do Brasil; 5) Resultados e análises da ressilabificação do rótico; e 6) Discussão e considerações finais.

\section{OS RÓTICOS E A ESTRUTURA PROSÓDICA}

Os primeiros trabalhos que focalizam a ressilabificação do rótico são os de Tenani (2002, 2003). Além da observação de outros fenômenos de sândi externo, a autora elabora experimentos de leitura de frases para verificar se a ressilabificação do rótico serviria de evidência segmental para a comprovação dos diversos constituintes da hierarquia prosódica e se haveria, dentre as fronteiras desses constituintes, um locus privilegiado para a aplicação do processo.

O experimento de leitura conduzido por Tenani (2002) contou com gravações de fala de seis informantes do sexo feminino, de 21 a 28 anos, com grau universitário, e residentes, na altura da coleta de dados, havia no mínimo quatro anos na região de São José do Rio Preto (SP); levou em conta onze tipos de sentenças, com quatro tipos de fronteiras prosódicas (mesmo $\varphi$, ou seja, fronteira de palavra prosódica $(\mathrm{Pw})$; entre $\varphi s$; entre IPs e entre Us - enunciados fonológicos) e controlou a extensão e a complexidade sintática dos constituintes relevantes para o sândi, tal como se pode ver nos exemplos extraídos do trabalho da autora (2002, p. 120):

(4) 1. [O açúcar amarelo $]_{\varphi}$ é mais saboroso.

2. $[\mathrm{O} \text { açúcar }]_{\phi}[$ alcançou $]$ bom preço.

3. O trabalho do produtor [de açúcar $]_{\varphi}[$ allcançou] bons resultados.

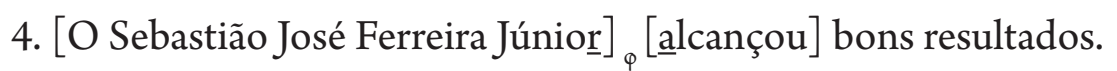

5. [O açúcar $]_{I}$ [appesar do especulador $]_{I}$ [âlcançou bom preço.]

6. [Somente dando açúcar] [ [alcançaram bons resultados na campanha.]

7. [Fábio vendeu açúcar. $]_{U}$ [ Alcançou bons resultados.]

8. [Fábio comeu açúcar. $]_{U}$ [ Aline tomou sorvete.]

9. [O Pedro comprou açúcar. $]_{U}$ [ Alegaram falta de provas. $]$

10. [O Paulo vendeu açúcar. $]_{U}$ [ㄹppresentou altos índices de produtividade.]

11. [O Marcos fez vários investimentos na produção de açúcar. $]_{U}$ [ Apresentou bons resultados.] 
Em síntese, os resultados de Tenani (2002, p. 121) revelam que a ressilabificação do rótico se aplica em todas as fronteiras prosódicas analisadas, independentemente do tamanho e da complexidade dos constituintes em questão. Os poucos dados de cada tipo de sentença - são seis no total - não permitem, na verdade, chegar a conclusões definitivas sobre a taxa de aplicação do processo por tipo de fronteira prosódica. Permitem, contudo, concluir que o processo não é bloqueado na fronteira de nenhum dos constituintes analisados e aventar a hipótese de que essa seja uma regra que se aplica variavelmente pelas fronteiras.

A partir dessas conjecturas, pudemos formular uma das questões principais desta pesquisa: seriam as taxas de ressilabificação do rótico diferentes nas diferentes fronteiras prosódicas, no sentido de haver maior probabilidade de ressilabificação em fronteiras mais baixas, como a de palavra prosódica $(\mathrm{Pw})$ e sintagma fonológico $(\mathrm{PhP})$, em relação à fronteira prosódica mais alta de sintagma entoacional (IP)? Essa regra segmental de reestruturação silábica envolve sempre a fronteira de palavra, que, a depender do contexto, pode coincidir com fronteiras de constituintes mais altos da hierarquia prosódica , as quais portam informações importantes do ponto de vista prosódico-entoacional, que poderiam atuar no sentido de inibir a aplicação da regra segmental.

Seguindo os passos de Tenani, Marcato (2013) descreve o comportamento das preposições monossilábicas também na variedade falada na região do Noroeste Paulista, buscando evidências sobre o estatuto prosódico de elementos clíticos em português. De todas as preposições analisadas e processos segmentais investigados, interessa-nos a prosodização de por e a possibilidade de ressilabificação do rótico. A autora utiliza 32 inquéritos de fala espontânea da amostra censo do banco de dados IBORUNA (http://www.iboruna.ibilce.unesp.br/) e analisa 252 dados de por seguidos de um vocábulo iniciado por uma vogal ( po[ra]lguns, po[re]xemplo, po[re]la, po[ri]sso, po[ro]tra, po[ru]ma - (MARCATO, 2013, p. 84)). Das ocorrências que apresentavam o contexto alvo para a aplicação do processo segmental, a autora encontrou 94,44\% (238/252) de passagem de uma consoante retroflexa do item por a tepe em posição de ataque silábico da palavra seguinte. Com isso, vemos que o processo é muito produtivo quando a fronteira prosódica é interna à Pw, ou seja, entre elemento clítico e palavra hospedeira acentuada lexicalmente.

Diferentemente dos estudos de Tenani, e na linha seguida por Marcato, utilizaremos amostras de fala espontânea e de uma quantidade de dados que nos permitirá, atra- 
vés de análise estatística variacionista, verificar se o tipo de fronteira prosódica é uma variável relevante para a ressilabificação do rótico em vocábulos não-clíticos.

Callou e Serra (2012) e Serra e Callou (2013, 2015), em estudos variacionistas, incluem a variável tipo de fronteira prosódica na observação da regra variável de cancelamento do rótico em coda final de palavra. Em Serra e Callou (2015), por exemplo, verificam que o processo é sensível à fronteira em que se encontra o segmento. As autoras comparam o português do Brasil (PB) ao português europeu (PE), com base em amostras de fala espontânea, gravadas nos anos 1990 e 2000 por mulheres jovens com grau universitário de escolaridade, nascidas no Rio de Janeiro e em Lisboa.

A análise estatística computacional de Serra e Callou revelou que o processo de apagamento do rótico em coda externa se encontra em estágios diferentes nas duas variedades do português: em termos labovianos (LABOV, 1994), a mudança sonora se encontra em vias de se completar no PB (76\%, input .77), enquanto no PE o cancelamento representa um processo novo e vigoroso (32\%, input .32) (2015, p. 103). Para o PB, além da classe morfológica e da dimensão do vocábulo que contém o rótico em coda final, a posição do $R$ relativamente ao tipo da fronteira prosódica também se mostrou uma variável significativa na análise multivariada empreendida pelas autoras. Assim, é na classe dos verbos $(.73,90 \%)$, em vocábulos com 3 ou mais sílabas $(.88,89 \%)$ e em fronteira de palavra prosódica $(.79,83 \%)$ que se apresentam os maiores índices de peso relativo e percentuais em favor do apagamento do rótico. Das cinco variáveis independentes levadas em conta pelas autoras, no PE, somente o tipo de fronteira prosódica mostrou-se significativo para a aplicação da regra variável, sendo as fronteiras mais baixas aquelas que favorecem mais o apagamento (Pw: .48, 35\%; PhP: .66, 40\%). Tanto em PB quanto em PE a fronteira de sintagma entoacional desfavorece a aplicação da regra variável: .27 (60\%) e .25 (24\%) de peso relativo, respectivamente.

A hipótese prosódica investigada pelas autoras confirma-se. A explicação para o apagamento do $R$ ser mais frequente nos níveis mais baixos que em nível mais alto da hierarquia prosódica é a de que, sendo o domínio de IP propenso a alongamentos pré-frontei$r a$, à inserção de pausas, e relevante para a entoação, pois é o constituinte a que se associam os eventos tonais nucleares (acentos tonais e tons de fronteira) das frases, sua fronteira direita atuaria como um contexto de resistência ao apagamento do rótico. No nosso entender, a manutenção do material segmental da sílaba final do sintagma entoacional, bem como das demais sílabas que compõem essa Pw cabeça de IP, seria fundamental para a realização dos eventos tonais nucleares das frases. 
Nesta pesquisa, guiar-nos-emos também por essa hipótese prosódica e buscaremos mapear os (possíveis) demais condicionamentos favorecedores da ressilabificação.

\section{APORTE TEÓRICO-METODOLÓGICO E MATERIAIS}

A pesquisa segue os passos metodológicos e os pressupostos teóricos da Sociolinguística Quantitativa (LABOV, 1994, 2001), que está relacionada a um modelo de estudo da mudança linguística que considera a língua como um organismo heterogêneo, frequentemente submetido a restrições tanto gramaticais quanto sociais para seu funcionamento.

Weinreich et al. (1968, p. 102) já haviam lançado uma proposta concreta de fundamentos empíricos para uma teoria da mudança linguística. Os autores postulam certos princípios e problemas a serem levados em consideração no estudo da mudança: (i) o problema das restrições ao uso de formas em variação (as condições para a mudança); (ii) o problema da transição (os estágios da mudança em progresso); (iii) o problema do encaixamento (o encaixamento da mudança na estrutura linguística, como um todo, e na estrutura social, no contexto mais amplo da comunidade de fala); (iv) o problema da avaliação (o nível de consciência do falante sobre o uso das variáveis); e (v) o problema da implementação (o processo de mudança linguística pode envolver estímulos e restrições, tanto da sociedade como da estrutura linguística).

Na busca de elucidar o estágio em que se encontra o processo de ressilabificação do rótico, o encaixamento da regra variável na estrutura linguística e na estrutura social e a atuação de estímulos e restrições para a difusão desse processo, faremos uso da análise estatística dos dados, numa perspectiva sociolinguística, com recurso ao pacote de programas GoldVarb X (SANKOFF; TAGLIAMONTE; SMITH, 2005). A identificação de oitiva dos tipos de realização do rótico é auxiliada pela análise acústica, realizada no programa PRAAT (BOERSMA; WEENINK, 2015).

A interpretação dos resultados lançará mão também dos pressupostos da chamada Teoria da Hierarquia Prosódica (NESPOR; VOGEL, 2007[1996]), uma teoria fonológica que propõe a segmentação do contínuo de fala em constituintes prosódicos hierarquicamente organizados em função das relações de proeminência acentual de cada nível. A partir da representação apresentada em Callou e Serra (2012), a seguir, podemos notar que a relação de proeminência relativa dentro de cada constituinte caracteriza-se pela ocorrência de um elemento como sendo o forte ( $s$-strong) e de todos os demais, na projeção máxima de cada domínio, como fracos $(w-w e a k)$. Em línguas como o português, 
de recursividade à direita, ou seja, cujas árvores sintáticas se ramificam à direita, a cabeça mais à direita é rotulada como $s$ e todos os demais elementos dentro da projeção máxima do constituinte são rotulados como $w$.

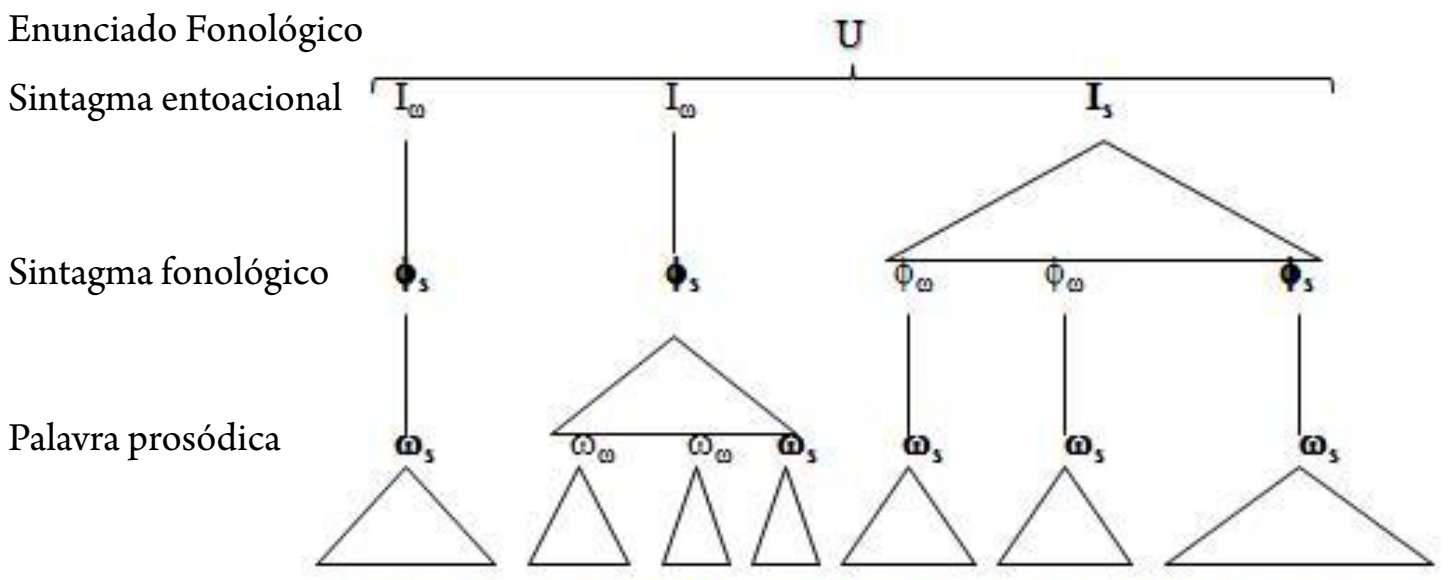

Sílaba

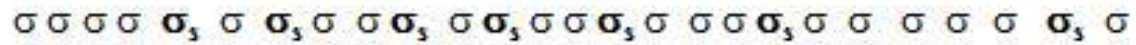
A exposição segundo ouvi dizer apresenta a pintura dos impressionistas

Figura 1: Estrutura prosódica e relação de proeminência relativa nos domínios prosódicos (CALLOU; SERRA, 2012, p. 48).

Levamos em conta na pesquisa a fronteira direita dos constituintes prosódicos $\mathrm{Pw}$ (do nome em inglês prosodic word), $\mathrm{PhP}$ (phonological phrase) e IP (intonational phrase). O algoritmo de formação da palavra prosódica prevê que esse constituinte tem um único acento primário (um grupo de palavra prosódica tem um único elemento proeminente). Todo elemento com acento de palavra tem de estar incluído numa palavra prosódica (VIGÁRIO, 2010). Um sintagma fonológico deve ser formado por uma cabeça lexical (núcleos de sintagmas sintáticos cuja natureza é lexical e não funcional), mais todos os elementos do lado esquerdo dentro da projeção máxima dessa cabeça e mais o XP complemento do seu lado direito, que contenha apenas uma $\mathrm{Pw}_{\mathrm{w}}$ (FROTA, 2000; TENANI, 2002). Dessa forma, atendendo às condições necessárias, um $\varphi$ deve ser constituído por mais do que uma palavra prosódica, formando um único $\varphi$ com um complemento não ramificado. Um sintagma entoacional deve conter toda sequência não estruturalmente anexada à oração raiz ou todas as sequências de $\varphi s$ em uma oração raiz (NESPOR; VOGEL, 2007[1996]). A formação de IP está sujeita a condições de tamanho prosódico: sintagmas longos (em número de sílabas e de palavras prosódicas) tendem a ser divididos, da mesma forma que sintagmas pequenos tendem a formar um único IP com um IP adjacente, o que leva à formação de sintagmas com tamanhos equilibrados (FROTA, 
2000; SERRA, 2009). Como dissemos nas páginas iniciais deste artigo, cada constituinte prosódico funciona como o locus de aplicação de processos segmentais e de eventos entoacionais os mais variados.

No que se refere aos materiais, foram utilizadas amostras de fala de 12 indivíduos nascidos em Curitiba (4), Florianópolis (4) e Porto Alegre (4), estratificadas por sexo - masculino e feminino, e idade - 18 a 30 anos e 50 a 65 anos, todos com nível superior completo - a chamada fala culta (Projeto Atlas Linguístico do Brasil - ALiB: Cardoso et al., 2014). O corpus do projeto $\mathrm{ALiB}$ é composto por questionários que se prestam à identificação de fenômenos linguísticos os mais variados: (i) questionário semântico-lexical (QSL); (ii) questionário morfossintático (QMS); e questionário fonético-fonológico (QFF), que inclui também questões para a realização da análise prosódica de enunciados declarativos, interrogativos e disjuntivos neutros. O corpus ainda inclui questões de pragmática, de natureza metalinguística, sugestões para temas do chamado discurso semidirigido, que corresponde a trechos de fala espontânea realizada a partir da proposição de um tema do cotidiano local, e um texto para leitura (Comitê Nacional do ALiB, 2001).

Nossos dados foram coletados dos momentos mais informais da entrevista dedicados à produção de fala espontânea do/a entrevistado/a. Foram descartados os dados que correspondiam a produções monovocabulares, muito frequentes como respostas às perguntas dos questionários mencionados acima. Por outro lado, foram considerados os dados pertencentes aos momentos da entrevista em que o informante, desviando-se um pouco das respostas aos questionários, passava a contar algum fato ocorrido, alguma lembrança suscitada a partir do conteúdo da conversa etc., além dos dados coletados do discurso semidirigido, que foi o foco inicial e principal da recolha.

Os procedimentos metodológicos incluíram a audição das gravações constitutivas do corpus, o levantamento e a codificação sociolinguística dos dados e a análise à luz das teorias apresentadas. O processamento estatístico dos dados levou em conta 11 variáveis linguísticas e sociais que permitem a verificação dos fatores relevantes à aplicação do sândi. As referidas variáveis constam do Quadro 1, a seguir, que inclui a variável dependente e as variáveis independentes testadas no estudo, bem como a exemplificação de cada fator. 


\begin{tabular}{|c|c|}
\hline \multirow{4}{*}{$\begin{array}{c}\text { Variável } \\
\text { dependente } \\
\text { (formas variantes) }\end{array}$} & Ressilabificação \\
\hline & (5) O luga[ro]nde o rio termina. (Informante 1 - Porto Alegre) \\
\hline & Não ressilabificação \\
\hline & (6) ...diz que ia fazer História ... (Informante 4 - Curitiba) \\
\hline \multirow{14}{*}{$\begin{array}{l}\text { Variáveis } \\
\text { independentes } \\
\text { linguísticas }\end{array}$} & Classe morfológica do vocábulo: verbo ou não-verbo \\
\hline & $\begin{array}{l}\text { (7) Eu tava viajando, eu tinha ido visitar uma tia. (Informante } 2 \\
\text { Florianópolis) } \\
\text { (8) ...aquela mulhe[re] mão-de-vaca, é pão-dura ... (Informante } 4 \text { - Porto } \\
\text { Alegre) }\end{array}$ \\
\hline & Dimensão do vocábulo que contém o $R$ : 1 sílaba ou 2 ou mais sílabas \\
\hline & $\begin{array}{l}\text { (9) Aqui, é muito raro se ver ovelha. (Informante } 1 \text { - Florianópolis) } \\
\text { (10) Cassiano, você está a fim de sair hoje? (Informante } 1 \text { - Curitiba) }\end{array}$ \\
\hline & $\begin{array}{l}\text { Dimensão do vocábulo que contém a vogal: } \\
1 \text { sílaba ou } 2 \text { ou mais sílabas }\end{array}$ \\
\hline & $\begin{array}{l}\text { (11) Vamos dar uma volta? (Informante } 3 \text { - Florianópolis) } \\
\text { (12) Eu quero saber se o meu amigo vai sair hoje ou se ele vai sair amanhã } \\
\text { (Informante } 4 \text { - Porto Alegre) }\end{array}$ \\
\hline & Qualidade da vogal do núcleo silábico que contém o $R$ : cada uma delas \\
\hline & $\begin{array}{l}\text { (13) Nossa, e eu pensei que não ia chov[e]r hoje... (Informante } 4 \\
\text { Curitiba) }\end{array}$ \\
\hline & $\begin{array}{l}\text { Qualidade da vogal do núcleo silábico seguinte: } \\
\text { cada uma delas }\end{array}$ \\
\hline & (14) Tem que misturar [a]gua. (Informante 2 - Porto Alegre) \\
\hline & Tonicidade da sílaba do núcleo silábico seguinte: átona ou tônica \\
\hline & $\begin{array}{l}\text { (15) Não me lembro, pelo menos, de ter ouvido. (Informante } 1 \\
\text { Florianópolis) } \\
\text { (16) ...você vai te[ra]lta hoje até o final do dia. (Informante } 1 \text { - Curitiba) }\end{array}$ \\
\hline & $\begin{array}{l}\text { Fronteira prosódica: palavra prosódica, sintagma fonológico ou sin- } \\
\text { tagma entoacional }\end{array}$ \\
\hline & $\begin{array}{l}\text { (17) A gente foi [patrocinar]Pw um campeonato. (Informante } 1 \\
\text { Curitiba) } \\
\text { (18) ...a gente ia muito na igreja com a minha vó pra [armar] } \varphi \text { o nasci- } \\
\text { mento de Jesus. (Informante } 4 \text { - Porto Alegre) } \\
\text { (19) [Senhor]IP, o senhor deixou cair a carteira. (Informante } 4 \text { - Porto } \\
\text { Alegre) }\end{array}$ \\
\hline
\end{tabular}




\begin{tabular}{|c|c|}
\hline \multirow{6}{*}{$\begin{array}{l}\text { Variáveis } \\
\text { independentes } \\
\text { sociais }\end{array}$} & Sexo: masculino ou feminino \\
\hline & $\begin{array}{l}\text { (20) Depende, se chama[ra] comida que eu faço de comida, eu gosto. } \\
\text { (Informante } 1 \text { - Curitiba) } \\
\text { (21) Eu queria laboratório ou dar aula. Informante } 2 \text { - Curitiba) }\end{array}$ \\
\hline & Faixa etária: 18-30 anos ou 56-65 anos) \\
\hline & $\begin{array}{l}\text { (22) Vai botar água dentro. (Informante } 1 \text { - Porto Alegre) } \\
\text { (23) Esse gravado[rq] teu. (Informante } 3 \text { - Porto Alegre) }\end{array}$ \\
\hline & Capital \\
\hline & $\begin{array}{l}\text { (24) Se fo[ra]ntes, eu posso vir aqui ainda dar um cheirinho na minha } \\
\text { mãe. (Informante } 2 \text { - Curitiba) } \\
\text { (25) ...eu já era casada e não tinha dinheiro pra fazer inscrição... } \\
\text { (Informante } 2 \text { - Florianópolis) } \\
\text { (26) ...o computado[re]ra um pouquinho melhor. (Informante } 1 \text { - Porto } \\
\text { Alegre) }\end{array}$ \\
\hline
\end{tabular}

Quadro 1: Variáveis testadas no processamento sociolinguístico dos dados de (não) ressilabificação do rótico.

Como não tivemos conhecimento de estudos sociolinguísticos que tratassem especificamente da ressilabificação do rótico, esta é uma primeira testagem de variáveis que podem exercer algum papel no processo fonológico; buscamos referências em pesquisas tanto sobre o cancelamento do rótico quanto em outras que focalizam outros fenômenos de sândi externo.

No que se refere, por exemplo, à classe morfológica do vocábulo, a separação binária em verbos (cantar) e não-verbos, fator que engloba todas as outras classes (p. ex., substantivo, adjetivo, advérbio etc.: mar, melhor, devagar), segue o que estabelecem pesquisas anteriores sobre o apagamento do $R$, que mostraram não ser produtiva a testagem de todas as classes morfológicas em separado. Relativamente à classificação binária dos grupos de fatores dimensão do vocábulo que contém o R e dimensão do vocábulo subsequente, seguimos também a tendência de estudos anteriores, no sentido de contrastar os monossílabos com os polissílabos.

\section{ANTES DE MAIS NADA: O APAGAMENTO DO $R$ NO SUL DO BRASIL}

A abordagem que faremos na próxima seção, sobre a ressilabificação do rótico, parece-nos estar intimamente relacionada ao processo de cancelamento do segmento: em hipótese, é na classe dos não-verbos que a ressilabificação se aplica mais frequentemente, 
ou seja, é nos vocábulos em que o rótico não porta marca morfológica que há menor propensão de apagamento e maior propensão de ressilabificação. Em função dessa hipótese de partida, buscamos os resultados de um estudo sociolinguístico recente sobre o $R$ nas capitais do Sul (SANTANA, 2017), que apresenta os índices de apagamento do $R$ e a distribuição dos róticos em cada região, a partir de amostras de fala também do Projeto ALiB.

Em sua análise, Santana (2017) confirma a tendência ao avanço do apagamento do $R$ já verificada em estudos anteriores realizados por Callou (1987), Monaretto (2002), Callou, Serra e Cunha (2015), entre outros, que dão conta do processo de variação e mudança na realização dos róticos, tanto em verbos quanto em não-verbos, nas diferentes regiões do país.

A autora encontra, no cômputo geral das três cidades, um percentual de apagamento de $89 \%$ (input .92), entre os verbos (5.282 dados), e 19\% de apagamento (input.11), entre os não-verbos (1247 dados). De capital a capital variam, entretanto, tanto os percentuais de cancelamento quanto os percentuais de ocorrência de cada variante do rótico.

Em Curitiba, o percentual de apagamento do rótico nos 1.838 dados de verbos é de $87 \%$ (input .91); há um total de 367 dados de não-verbos e apenas $5 \%$ de apagamento (input .05). Em termos de distribuição das realizações do rótico, em verbos (13\% de realização) e não-verbos (95\% de realização), Santana encontrou o que podemos visualizar a seguir, nos Gráficos 1 e 2.

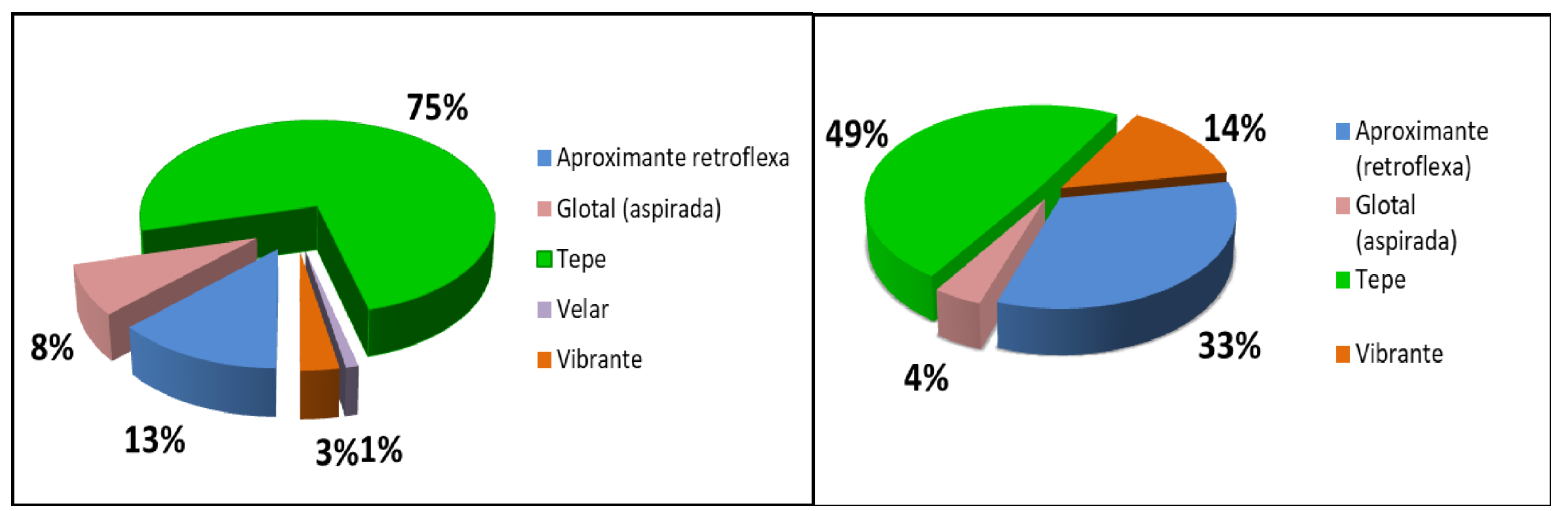

Gráfico 1: Distribuição da realização do $R$ em verbos, em Curitiba (SANTANA, 2017, p.70).
Gráfico 2: Distribuição da realização do $R$ em não-verbos, em Curitiba (SANTANA, 2017, p.88).

Como vemos, predomina o tepe na capital paranaense, independentemente da classe morfológica do vocábulo, embora entre os não-verbos a retroflexa alcance índice bastante expressivo (33\%). As fricativas (velar e glotal) respondem por percentuais mui- 
to baixos e a vibrante aparece mais na realização dos não-verbos (14\%) do que na dos verbos $(3 \%)$.

Cenário bastante distinto é o descrito pela autora para a cidade de Florianópolis entre os não-verbos: houve 41\% (input .38) de apagamento em 473 dados desta capital, percentual bastante superior ao encontrado em Curitiba (5\%), o que sugere estágios diferentes da mudança nas capitais. Entre os verbos, o percentual de apagamento também é mais alto do que o encontrado na capital paranaense: 94\% (input .98), em 2.058 dados de verbos. A distribuição dos tipos de realização do $R$ em verbos ( $6 \%$ de realização) e não-verbos (59\% de realização) é apresentada nos Gráficos 3 e 4 a seguir.

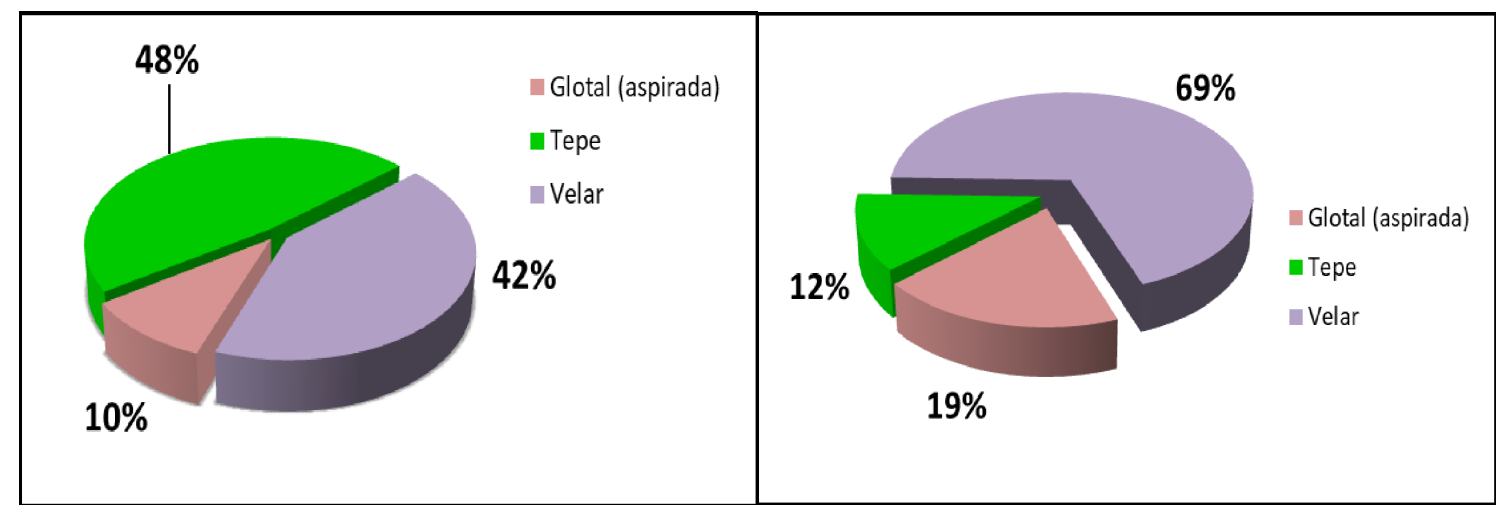

Gráfico 3: Distribuição da realização do $R$ em verbos, em Florianópolis (SANTANA, 2017, p. 75).
Gráfico 4: Distribuição da realização do $R$ em não-verbos, em Florianópolis (SANTANA, 2017, p. 89).

Em termos de realização, vemos que entre os verbos o tepe sofre a concorrência da fricativa velar, enquanto nos não-verbos esta última prevalece na pronúncia do florianopolitano (69\%) e o percentual de tepe fica abaixo do da fricativa glotal.

Na cidade de Porto Alegre, o número de dados de verbos contabilizado foi de 1.386, com $86 \%$ de apagamento (input .87). Entre os não-verbos foram analisados 407 dados e o cancelamento do rótico alcançou somente 7\% do cômputo geral (input .03), resultados próximos aos de Curitiba. Em termos das variantes mais frequentemente realizadas na capital gaúcha, Santana registra o que consta dos Gráficos 5 e 6, a seguir, para verbos (14\% de realização) e não- verbos (93\% de realização). 


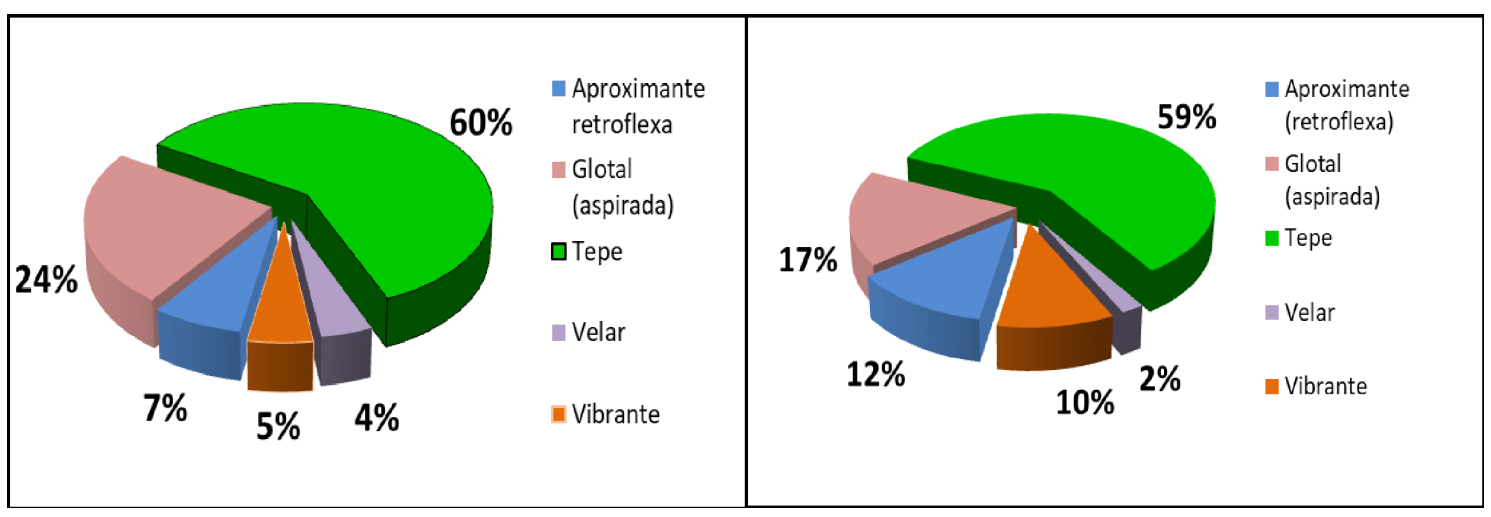

Gráfico 5: Distribuição da realização do $R$ em verbos, em Porto Alegre (SANTANA, 2017, p. 81).
Gráfico 6: Distribuição da realização do $R$ em não-verbos, em Porto Alegre

(SANTANA, 2017, p. 93).

Florianópolis se mostra a capital mais inovadora da região Sul, tanto em termos de avanço do cancelamento do rótico quanto em termos de utilização de variantes mais inovadoras (fricativas). Santana (2017) busca relacionar os resultados de sua pesquisa à formação sócio-histórica das localidades e ao Índice de Desenvolvimento Humano (IDH), que mede a qualidade de vida pautada nos parâmetros da educação, da longevidade e da renda, na tentativa de aliar a história linguística à história social das capitais.

Na próxima seção, poderemos verificar se também para o processo de ressilabificação do rótico os falantes da capital catarinense apresentam comportamento diferenciado do de curitibanos e porto-alegrenses.

\section{RESULTADOS E ANÁLISES DA RESSILABIFICAÇÃO DO RÓTICO}

Contendo o contexto alvo para a ressilabificação do rótico, foram levantados e analisados, em Curitiba, 56 dados de não-verbos e 353 de verbos (total de 409 ocorrências); em Florianópolis, 50 dados de não-verbos e 418 em verbos (total de 468 ocorrências) e em Porto Alegre, 53 dados de não-verbos e 206 de verbos (total de 259 ocorrências).

O processamento estatístico dos dados feito no programa Goldvarb X (SANKOFF et al., 2005) selecionou as variáveis favorecedoras da regra de ressilabificação em cada uma das capitais. Antes de passar para a análise por localidade, apresentamos a seguir o resultado geral de ressilabificação.

\subsection{Resultado geral das três capitais}

De um total de 1.136 dados, incluindo verbos e não-verbos, houve ressilabificação em $19,6 \%$ dos casos (input 0.19, sig. 0.000). A rodada estatística geral apontou o grupo 
de fatores capital (em $3^{\circ}$ lugar na ordem de seleção, das seis variáveis selecionadas) como relevante para a aplicação da regra variável, razão pela qual decidimos realizar rodadas individuais para cada capital (v. 5.2, 5.3 e 5.4).

Como podemos observar na Tabela 1 , a ressilabificação do rótico é mais provável de ocorrer na cidade de Curitiba (P.R. .56) e, mais ainda, na de Porto Alegre (P.R. .67), do que em Florianópolis (P.R. .34). Em todas as tabelas apresentamos o número de ocorrências de dados com ressilabificação sobre o total, o respectivo percentual e os pesos relativos calculados e indicados como estatisticamente significativos pelo programa Goldvarb X.

Tabela 1: Distribuição da ressilabificação do rótico de acordo com a capital

\begin{tabular}{|c|c|c|c|}
\hline Capital & Ocorrências/Total & Percentual & Peso Relativo \\
\hline Curitiba & $84 / 409$ & $20,5 \%$ & $\mathbf{0 . 5 6}$ \\
\hline Florianópolis & $61 / 468$ & $13 \%$ & 0.34 \\
\hline Porto Alegre & $78 / 259$ & $30,1 \%$ & $\mathbf{0 . 6 7}$ \\
\hline
\end{tabular}

Nossos resultados vão ao encontro, portanto, da hipótese de que na cidade em que o processo de cancelamento do rótico já se encontra mais avançado há menor favorecimento da ressilabificação do segmento em onset.

\subsection{Curitiba}

De um total de 409 dados dos falantes curitibanos, houve ressilabificação em 20,5\% dos casos (input 0.20, sig. 0.000), como se pode verificar no Gráfico 7, a seguir. Em (27) e (28), respectivamente, encontramos exemplos de aplicação e de não aplicação do processo por falantes de Curitiba.

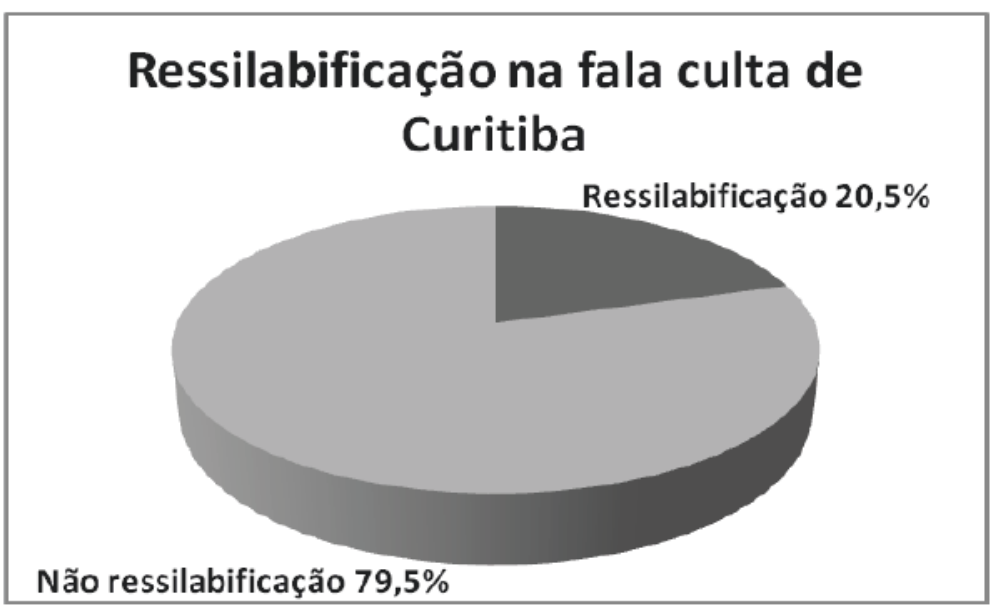

Gráfico 7: Percentual geral de ressilabificação do rótico - Curitiba. 
(27) Tem o nome de um lugar meno[ra]inda que uma chácara. (Informante 2 Curitiba)

(28) Aí, fazer alguns afazeres domésticos ou mesmo assistir televisão. (Informante 3 - Curitiba)

As variáveis indicadas pelo programa estatístico para Curitiba foram, por ordem de seleção: 1 ) o tipo de vogal na sílaba portadora do $R ; 2$ ) a dimensão do vocábulo portador do $R ; 3)$ a classe morfológica do vocábulo; e 4) o tipo de fronteira prosódica. A primeira delas é apresentada na Tabela 2 e exemplos com as vogais [0] e [o] são fornecidos em (29) e (30), a seguir.

Tabela 2: Distribuição da ressilabificação do rótico de acordo com a vogal na sílaba portadora do $R$ - Curitiba

\begin{tabular}{|c|c|c|c|}
\hline \multicolumn{5}{|c|}{ Tipo de vogal na sílaba portadora do $\boldsymbol{R}$} \\
\hline Vogal & Ocorrências/Total & Percentual & Peso Relativo \\
\hline$[\mathrm{a}]$ & $20 / 199$ & $10,1 \%$ & 0.43 \\
\hline$[\mathrm{e}]$ & $28 / 116$ & $24,1 \%$ & 0.48 \\
\hline$[\mathrm{i}]$ & $4 / 34$ & $11,8 \%$ & 0.44 \\
\hline$[\mathrm{J}]$ & $\mathbf{3 / 4}$ & $\mathbf{7 5 \%}$ & $\mathbf{0 . 9 4}$ \\
\hline$[\mathrm{o}]$ & $\mathbf{2 9 / 4 5}$ & $\mathbf{6 4 , 4 \%}$ & $\mathbf{0 . 7 9}$ \\
\hline
\end{tabular}

(29) É que uma é maio[ro]utra é menor... (Informante 4 - Curitiba)

(30) Tem o (ônibus) alimentador, né, que nem alimentado[ra]nda só no conjunto. (Informante 2 - Curitiba)

Vemos que, quando as vogais portam o traço [+rec], o peso relativo para a aplicação da regra é alto ([0] 0.94, ex. (29); [o] 0.79, ex. (30)), ao passo que, para as demais vogais, o índice estatístico permanece próximo do neutro. No que se refere a $[\varepsilon]$, em todos os 11 dados em que a vogal ocorreu não houve ressilabificação. E não foram encontrados dados com a vogal $[\mathrm{u}]$ no contexto alvo para a aplicação do processo.

Nos exemplos (31) e (32), respectivamente, encontramos dados que ilustram a ressilabificação em vocábulo monossilábico portador do $R$ e a não ressilabificação em vocábulo com mais sílabas, tendência atestada pelos pesos relativos da Tabela 3 , a seguir, que indicam o favorecimento da ressilabificação entre os monossílabos (P.R. 0.89). 
Tabela 3: Distribuição da ressilabificação do rótico de acordo com a dimensão do vocábulo portador do $R$ - Curitiba

\begin{tabular}{|c|c|c|c|}
\hline \multicolumn{5}{|c|}{ Dimensão do vocábulo portador do $\boldsymbol{R}$} \\
\hline Dimensão & Ocorrências/Total & Percentual & Peso Relativo \\
\hline Uma sílaba & $\mathbf{3 6 / 6 8}$ & $\mathbf{5 2 , 9 \%}$ & $\mathbf{0 . 8 9}$ \\
\hline Mais de uma sílaba & $48 / 341$ & $14,1 \%$ & 0.39 \\
\hline
\end{tabular}

(31) É, tinha que te[re]studado antes. (Informante 2 - Curitiba)

(32) Ou fazer alguma coisa que tem fazer com relação a algum trabalho... (Informante 3 - Curitiba)

A Tabela 4 e os exemplos (33) e (34) a seguir mostram o favorecimento da passagem do rótico em coda silábica a onset em vocábulos não verbais (P.R. 0.92) e seu desfavorecimento quando o item é um verbo (P.R. .39). A classificação morfológica diz respeito ao primeiro vocábulo do par envolvido no sândi externo.

Tabela 4: Distribuição da ressilabificação do rótico

de acordo com a classe morfológica do vocábulo - Curitiba.

\begin{tabular}{|c|c|c|c|}
\hline \multicolumn{4}{|c|}{ Classe morfológica do vocábulo } \\
\hline Classe & Ocorrências/Total & Percentual & Peso Relativo \\
\hline Verbo & $52 / 353$ & $14,7 \%$ & 0.39 \\
\hline Não-verbos & $\mathbf{3 2} / \mathbf{5 6}$ & $\mathbf{5 7 , 1 \%}$ & $\mathbf{0 . 9 2}$ \\
\hline
\end{tabular}

(33) Douto[re]u vou sair hoje? (Informante 1 - Curitiba)

(34) Eu prefiro falar arco. (Informante 2 - Curitiba)

A seguir, na Tabela 5, confirma-se a maior tendência de aplicação da ressilabificação do rótico nas fronteiras mais baixas de palavra prosódica $(\mathrm{Pw})$ e de sintagma fonológico $(\mathrm{PhP})$, sendo o processo inibido quando a fronteira prosódica em que se encontra o rótico é a de sintagma entoacional (IP). Os exemplos (35), (36) e (37) ilustram a ocorrência de ressilabificação nas duas primeiras fronteiras e sua não ocorrência na última.

Tabela 5: Distribuição da ressilabificação do rótico

de acordo com a fronteira prosódica - Curitiba 


\begin{tabular}{|c|c|c|c|}
\hline \multicolumn{4}{|c|}{ Tipo de fronteira prosódica } \\
\hline Fronteira & Ocorrências/Total & Percentual & Peso Relativo \\
\hline Pw & $\mathbf{3 2 / 1 6 7}$ & $\mathbf{1 9 , 2 \%}$ & $\mathbf{0 . 5 7}$ \\
\hline PhP & $\mathbf{3 2 / 1 2 8}$ & $\mathbf{2 5 \%}$ & $\mathbf{0 . 6 9}$ \\
\hline IP & $20 / 114$ & $17,5 \%$ & 0.20 \\
\hline
\end{tabular}

(35) Pw - Se fo[rĩ]nverno, eu dou a ordem: Saia daí, menino, que você vai ficar resfriado. (Informante 4 - Curitiba)

(36) $\mathrm{PhP}$ - Ah, basicamente a gente supriria as necessidades básicas iniciais, né, que é você te[rũ]ma moradia melhor, né... (Informante 3 - Curitiba)

(37) IP-Não, de acordo com a profissão ele vai capinar, é carpinteiro... (Informante 1 - Curitiba)

\subsection{Florianópolis}

Entre os falantes florianopolitanos, de um total de 468 dados, houve ressilabificação em apenas $13 \%$ dos casos (input 0.13, sig. 0.024) - Gráfico 8 e exemplos (38) e (39), sendo as variáveis selecionadas pelo Goldvarb as seguintes: 1) a classe morfológica do vocábulo; 2) a dimensão do vocábulo portador do $R$; 3 ) o tipo de vogal na sílaba subsequente ao $R$; e 4) o tipo de fronteira prosódica.

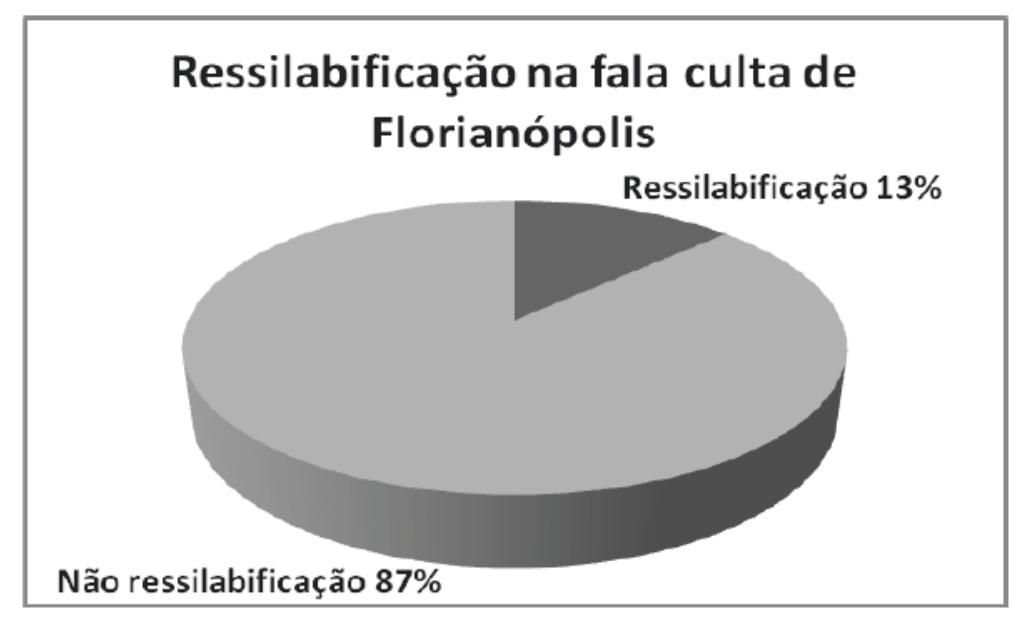

Gráfico 8: Percentual geral de ressilabificação - Florianópolis.

(38) Marilza, quer beber alguma coisa? (Informante 1 - Florianópolis)

(39) No popula[ra]caba falando que é burro. (Informante 2 - Florianópolis) 
Na cidade de Florianópolis, que apresenta o menor input em favor da ressilabificação, são muito semelhantes os condicionamentos para a aplicação do processo variável. A classe morfológica é o fator mais atuante para o processo, novamente com os vocábulos não verbais propiciando-o mais (Tabela 6: P.R. 0.99; ex. (40)) relativamente aos verbos (Tabela 6: P.R. 0.35; ex. (41)).

Tabela 6: Distribuição da ressilabificação do rótico de acordo com a classe morfológica do vocábulo - Florianópolis

\begin{tabular}{|c|c|c|c|}
\hline \multicolumn{4}{|c|}{ Classe morfológica do vocábulo } \\
\hline Classe & Ocorrências/Total & Percentual & Peso Relativo \\
\hline Verbo & $27 / 418$ & $6,5 \%$ & 0.35 \\
\hline Não-verbos & $34 / 50$ & $68 \%$ & $\mathbf{0 . 9 9}$ \\
\hline
\end{tabular}

(40) A co[rẽ] carnado é a cor da carne, né, deve ser... (Informante 3 - Florianópolis)

(41) Então eu deixo pra tomar o meu café aqui na escola lá pelas nove e meia... (Informante 4 - Florianópolis)

Assim como em Curitiba, na capital catarinense a dimensão do vocábulo portador do $R$ foi a segunda variável a ser selecionada na rodada estatística, novamente com os vocábulos de uma sílaba favorecendo a ressilabificação do rótico (Tabela 7: P.R. 0.79; ex. (42)) e com os polissílabos indo na direção contrária (Tabela 7: P.R. 0.42; ex. (43)).

Tabela 7: Distribuição da ressilabificação do rótico de acordo com a dimensão do vocábulo - Florianópolis

\begin{tabular}{|c|c|c|c|}
\hline \multicolumn{4}{|c|}{ Dimensão do vocábulo portador do $\boldsymbol{R}$} \\
\hline Dimensão & Ocorrências/Total & Percentual & Peso Relativo \\
\hline Uma sílaba & $21 / 86$ & $24,4 \%$ & $\mathbf{0 . 7 9}$ \\
\hline $\begin{array}{c}\text { Mais de uma } \\
\text { sílaba }\end{array}$ & $40 / 382$ & $10,5 \%$ & 0.42 \\
\hline
\end{tabular}

(42) Boteco? Não, ou é o ba[row] boteco. (Informante 4 - Florianópolis)

(43) ...enquanto não houver um financiamento público de campanha pra que todos possam gastar dentro daqueles limites... (Informante 3 - Florianópolis) 
Na observação do tipo de vogal, desta vez aquele pertencente à sílaba do vocábulo subsequente ao rótico, percebemos a mesma tendência verificada em Curitiba: a dos vocábulos portadores de núcleos [+rec] favorecerem mais a ressilabificação, como se nota na Tabela 8, a seguir, e nos exemplos (44) e (45) que a sucedem. Os dados com vogal [u], também $[+\mathrm{rec}]$, retornam um peso relativo muito próximo do neutro.

Tabela 8: Distribuição da ressilabificação do rótico de acordo com a vogal na sílaba subsequente ao $R$ - Florianópolis

\begin{tabular}{|c|c|c|c|}
\hline \multicolumn{5}{|c|}{ Tipo de vogal na sílaba subsequente ao $\boldsymbol{R}$} \\
\hline Vogal & Ocorrências/Total & Percentual & Peso Relativo \\
\hline$[$ a] & $29 / 169$ & $17,2 \%$ & $\mathbf{0 . 7 3}$ \\
\hline$[\varepsilon]$ & $2 / 22$ & $9,1 \%$ & 0.11 \\
\hline$[\mathrm{e}]$ & $8 / 49$ & $16,3 \%$ & 0.30 \\
\hline$[\mathrm{i}]$ & $3 / 39$ & $7,7 \%$ & 0.10 \\
\hline$[\mathrm{\jmath}]$ & $2 / 4$ & $50 \%$ & $\mathbf{0 . 6 7}$ \\
\hline$[\mathbf{o}]$ & $5 / 28$ & $17,9 \%$ & $\mathbf{0 . 5 7}$ \\
\hline$[\mathrm{u}]$ & $12 / 157$ & $7,6 \%$ & 0.48 \\
\hline
\end{tabular}

(44) Sim, você vai recebe[ra]lta. (Informante 1 - Florianópolis)

(45) Puxa, hoje tá difícil na minha situação, se eu de[ro]rdem, é capaz deles saírem. (Informante 3 - Florianópolis)

Em relação ao tipo de fronteira prosódica em que se encontra o $R$ em coda, novamente a fronteira de IP inibe a atuação do processo de ressilabificação do rótico (Tabela 9: P.R. 0.31; ex. (48)). Em Florianópolis, entretanto, as fronteiras mais baixas de $\mathrm{Pw}$ (Tabela 9: P.R. 0.63; ex. (46)) e de PhP (Tabela 9: P.R. 0.35; ex. (47)) se comportam diferentemente, somente a primeira delas favorecendo a aplicação do processo.

Tabela 9: Distribuição da ressilabificação do rótico de acordo com a fronteira prosódica - Florianópolis

\begin{tabular}{|c|c|c|c|}
\hline \multicolumn{4}{|c|}{ Tipo de fronteira prosódica } \\
\hline Fronteira & Ocorrências/Total & Percentual & Peso Relativo \\
\hline Pw & $30 / 251$ & $12 \%$ & $\mathbf{0 . 6 3}$ \\
\hline PhP & $18 / 136$ & $13,2 \%$ & 0.35 \\
\hline IP & $13 / 81$ & $16 \%$ & 0.31 \\
\hline
\end{tabular}


(46) $\mathrm{Pw}$ - ...não me lembro de te[ro]uvido o nome disso. (Informante 1 Florianópolis)

(47) $\mathrm{PhP}$ - Mas as pessoas falam que quando o céu tá estrelado, no outro dia vai dar dia bom, vai dar um dia bonito de sol. (Informante 2 - Florianópolis)

(48) IP - Através do serviço social a gente começou a trabalhar, eu milito desde os dezesseis anos... (Informante 3 - Florianópolis)

\subsection{Porto Alegre}

Em Porto Alegre, de um total de 259 dados, houve ressilabificação em 30,1\% dos casos (input 0.30, sig. 0.049) - Gráfico 9, exemplos (49) e (50). As variáveis selecionadas pelo Goldvarb são as seguintes: 1) a classe morfológica do vocábulo; 2) o tipo de vogal na sílaba portadora do $R$; e 3) a faixa etária do falante.

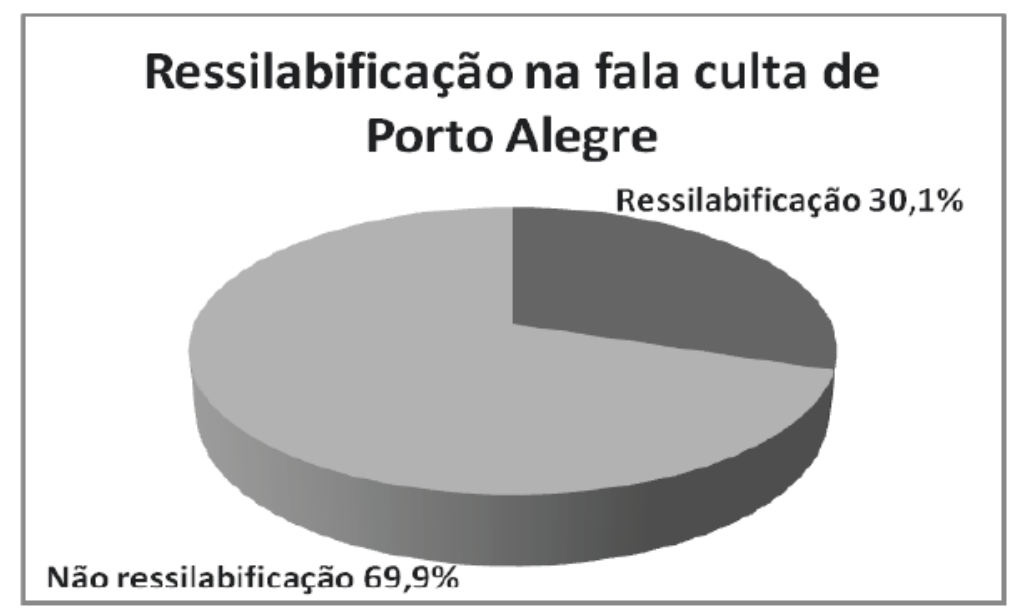

Gráfico 9: Percentual geral de ressilabificação - Porto Alegre.

(49) Ah, esse é o nosso mento[re]spiritual. (Informante 2 - Porto Alegre)

(50) Se olhar muito nitidamente, de repente, pode encontrar alguma coisa. (Informante 3 - Porto Alegre)

Seguindo a mesma tendência do que foi verificado em Curitiba e em Florianópolis, também em Porto Alegre os não-verbos favorecem a ressilabificação, como se pode verificar na Tabela 10 e nos exemplos (51) e (52), a seguir, que ilustram a aplicação do processo em um verbo e um não-verbo, respectivamente. 
Tabela 10: Distribuição da ressilabificação do rótico de acordo com a classe morfológica do vocábulo - Porto Alegre

\begin{tabular}{|c|c|c|c|}
\hline \multicolumn{4}{|c|}{ Classe morfológica do vocábulo } \\
\hline Classe & Ocorrências/Total & Percentual & Peso Relativo \\
\hline Verbo & $28 / 206$ & $13,6 \%$ & 0.25 \\
\hline Não-verbos & $\mathbf{5 0} / \mathbf{5 3}$ & $\mathbf{9 4 , 3 \%}$ & $\mathbf{0 . 9 8}$ \\
\hline
\end{tabular}

(51) Talvez eu posso procurar algo semelhante, mas com outro nome... (Informante 1 - Porto Alegre)

(52) Dizem que a torcida maio[re] a Gremista, né? (Informante 4 - Porto Alegre)

No que diz respeito à atuação das vogais nas sílabas portadoras do $R$ (Tabela 11), além do favorecimento da vogal [o] ([+rec]), no exemplo (54), e da ocorrência categórica de ressilabificação nos dados com vogal [0] (12 dados), também [+rec], notamos o desfavorecimento da aplicação da regra com a vogal [a], igualmente [+rec], e a novidade de também a vogal [i] ([-rec]), no exemplo (53), favorecer a ressilabificação nos dados dos falantes porto-alegrenses.

Tabela 11 : Distribuição da ressilabificação do rótico de acordo com a vogal na sílaba portadora do $R$ - Porto Alegre

\begin{tabular}{|c|c|c|c|}
\hline \multicolumn{5}{|c|}{ Tipo de vogal na sílaba portadora do $\boldsymbol{R}$} \\
\hline Vogal & Ocorrências/Total & Percentual & Peso Relativo \\
\hline$[\mathrm{a}]$ & $20 / 117$ & $17,1 \%$ & 0.35 \\
\hline$[\mathrm{e}]$ & $8 / 65$ & $12,3 \%$ & 0.42 \\
\hline$[\varepsilon]$ & $5 / 11$ & $45,5 \%$ & 0.14 \\
\hline$[\mathrm{i}]$ & $\mathbf{1 1 / 3 0}$ & $\mathbf{3 6 , 7 \%}$ & $\mathbf{0 . 8 0}$ \\
\hline$[\mathbf{0}]$ & $\mathbf{2 2 / 2 4}$ & $\mathbf{9 1 , 7 \%}$ & $\mathbf{0 . 9 4}$ \\
\hline
\end{tabular}

(53) Eu quero saber se o meu amigo vai sai[ro]je ou se ele vai sai[ra]manhã? (Informante 4 - Porto Alegre)

(54) Não, aqui não tem, mas no interio[ra]inda tem parteira. (Informante 4 Porto Alegre) 
Pela primeira vez entre as quatro rodadas estatísticas realizadas, uma variável social é selecionada como favorecedora da ressilabificação do rótico (Tabela 12). A faixa etária é apontada como uma variável importante, sendo os falantes mais velhos da capital gaúcha os que realizam mais o processo (P.R. 0.59). Exemplos da fala de indivíduos mais jovens e mais velhos são apresentados em (55) e (56), respectivamente.

Tabela 12: Distribuição da ressilabificação do rótico de acordo com a faixa etária dos informantes - Porto Alegre

\begin{tabular}{|c|c|c|c|}
\hline \multicolumn{4}{|c|}{ Faixa Etária } \\
\hline Faixa & Ocorrências/Total & Percentual & Peso Relativo \\
\hline $18-30$ anos & $27 / 117$ & $23,1 \%$ & 0.38 \\
\hline $\mathbf{5 0 - 6 5}$ anos & $\mathbf{5 1 / 1 4 2}$ & $\mathbf{3 5 , 5 \%}$ & $\mathbf{0 . 5 9}$ \\
\hline
\end{tabular}

(55) Nunca vi uma estrela cadente pra dizer essa frase. (Informante 2 - Porto Alegre)

(56) ...a benzedeira que é mulhe[re]xiste o curandeiro que o é homem. (Informante 3 - Porto Alegre)

\section{DISCUSSÃO E CONSIDERAÇÕES FINAIS}

No início deste artigo, propusemo-nos a focalizar o processo variável de ressilabificação do rótico em contexto de coda silábica externa diante de vogal iniciando vocábulo subsequente e sua relação com as fronteiras dos constituintes prosódicos no português falado na região Sul do Brasil. Buscamos também evidências em estudos sociolinguísticos sobre o cancelamento do rótico para a própria formulação de nossas hipóteses e dos grupos de fatores, linguísticos e sociais que pudessem atuar na aplicação do processo.

Ao fim desta primeira etapa da pesquisa, chegamos à conclusão de que estamos de fato no começo. Se, por um lado, constatamos o que era muito provável, o fato de o processo de ressilabificação atuar de forma espelhada relativamente ao processo de cancelamento, por outro, constatamos também que há algumas diferenças no comportamento linguístico de falantes das capitais estudadas. No que se refere ao que estamos chamando de espelhamento, voltamos aos resultados para elucidar a questão: no estudo de Santana (2017), vimos que Florianópolis é a cidade que lidera o processo de mudança em favor do apagamento do $R$, apresentando os maiores input em verbos (input .98) e não- verbos (input .38); sendo seguida por Curitiba, em verbos (input.91) e não-verbos (input .05), e Porto Alegre, em verbos (input .87) e não-verbos (input.05); estas últimas apresentando 
comportamento mais conservador, principalmente na classe dos não-verbos. Em nossa pesquisa, inversamente, é Porto Alegre que apresenta o maior índice de ressilabificação do rótico (input .30), seguida por Curitiba (input .20) e, finalmente, por Florianópolis, com o menor input para a aplicação do processo (input .13). Ou seja, nas cidades onde o rótico é menos cancelado, ele é mais ressilabificado em onset.

Verificamos que, assim como acontece para o apagamento, o processo de ressilabificação é sensível à classe morfológica do vocábulo: em todas as capitais, a ressilabificação em não-verbos é favorecida, enquanto o cancelamento é favorecido na classe dos verbos, já que nestes o rótico é uma marca morfológica redundante para indicar o infinitivo/subjuntivo verbal, concorrrendo com a marca prosódica do acento de palavra e perdendo para ela. A dimensão do vocábulo que contém o $R$ é uma variável significativa para duas das capitais (Curitiba e Florianópolis) e a tendência é a mesma: a de vocábulos monossilábicos propiciarem a ressilabificação, indo ao encontro dos resultados sobre o cancelamento do rótico, que indicam que esse é mesmo um contexto de preservação do segmento, devido à sua maior saliência fônica em vocábulos pequenos.

A hipótese prosódica que testamos, segundo a qual há maior probabilidade de ressilabificação em fronteiras mais baixas, como a de palavra prosódica e sintagma fonológico, em relação à fronteira prosódica mais alta de sintagma entoacional, confirmou-se parcialmente. A variável fronteira prosódica foi selecionada nas rodadas estatísticas de Curitiba e Florianópolis, mas os tipos de fronteira tiveram atuação um pouco diferentes em cada cidade. Confirma-se para Curitiba a hipótese de as fronteiras mais baixas, ou seja, as fronteiras internas da oração/do sintagma entocional, favorecerem a ressilabificação; e a fronteira direita do sintagma entocional — locus de associação do acento nuclear das sentenças, de inserção de pausas etc. - desfavorecerem-nas. Em Florianópolis, a fronteira de IP segue desfavorecendo o processo e a de $\mathrm{Pw}$ favorecendo-o robustamente, mas na fronteira de $\mathrm{PhP}$, intermediária entre os dois domínios anteriores, o fenômeno se comporta como na fronteira de IP, exigindo de nós mais trabalho futuro sobre esses e novos resultados a serem gerados.

A qualidade das vogais envolvidas no contexto segmental do sândi externo foi apontada também como significativa nas rodadas das três capitais. A atuação do tipo de vogal subsequente, entretanto, deve ser melhor investigada por meio de uma tabulação cruzada entre essa variável e o tipo de vogal antecedente ao rótico, a verificar-se a tendência maior/menor de vogais semelhantes entre si propiciarem ou não a ressilabificação. Além disso, com base nos resultados, podemos pensar que as vogais de articulação não aproxi- 
mada da articulação dos róticos (em cada região) poderiam favorecer a ressilabificação, assim como a semelhança articulatória é apontada como propiciadora do cancelamento. Muitos estudos sociolinguísticos sobre o cancelamento do rótico revelam também que é entre os mais jovens que mais se observa o apagamento do segmento; de forma especular, é entre os mais velhos, em Porto Alegre, que é mais provável haver a ressilabificação.

Finalmente, cabe um comentário sobre o possível estágio de mudança em que se encontra o processo de ressilabificação do rótico, após um panorama, ainda pouco definido, do encaixamento da regra variável na estrutura linguística e na estrutura social e a atuação de estímulos e restrições para a difusão do processo. Não se pode tirar conclusões sobre mudança linguística, primeiramente, porque as amostras de fala utilizadas aqui contemplam indivíduos com apenas duas faixas etárias, com uma lacuna temporal entre as gerações, o que não possibilita a observação do comportamento dos falantes nas diversas faixas etárias. Depois, observando os índices de aplicação da ressilabificação nas capitais, poderíamos pensar que se trata de um processo novo e vigoroso (LABOV, 1994), mas, levando em conta tudo o que se disse até aqui, percebemos que, na verdade, a ressilabificação parece ser recessiva, por estar intimamente ligada e dependente do processo de cancelamento do rótico, podendo atuar basicamente nos contextos em que ele (ainda) não atua. Veremos, com o tempo, se sua tendência será a de se expandir ou a de se tornar apenas residual no português do Brasil.

\section{Referências}

ABAURRE, M. B.; SÂNDALO, M. F. Os róticos revisitados. In: HORA, Dermeval da; COLLISCHONN, Gisela. Teoria linguística: fonologia e outros temas. João Pessoa: Editora da UFPB, p.144-180, 2003.

BISOL, L. O sândi e a ressilabação. Letras de Hoje, v. 31, n. 2, p. 159-168, 1996.

. A degeminação e a elisão no VARSUL. In: Bisol, L.; Brescancini, C. (Org.). Fonologia e variação: recortes do português brasileiro. Porto Alegre: EDIPUCRS, p.231250, 2002.

BOERSMA, P.; WEENINK, D. Praat: doing phonetics by computer [Computer program]. Versão 5.4.08, 2015 (disponível em www.praat.org).

CALLOU, D. M. I. Variação e Distribuição da Vibrante Na Fala Culta do Rio de Janeiro. Rio de Janeiro: UFRJ/PROED, 1987.

CALLOU, D. M. I, SERRA, C. R. Variação do rótico e estrutura prosódica. Revista do GELNE (UFC), v. 1, p. 41-57, 2012.

CALLOU, D.; SERRA, C.; CUNHA, C. Mudança em curso no português do Brasil. O pagamento do R no dialeto nordestino. ABRALIN, v.14, n.1, p. 195-219, jan./jun. 2015. 
CARDOSO, S. et al. Atlas linguístico do Brasil. Cartas linguísticas, vol. 2. Londrina: EDUEL, 2014.

COMITÊ NACIONAL DO ALIB (Brasil). Atlas Linguístico do Brasil: questionário 2001/ Comitê Nacional do projeto ALiB. Londrina: Ed. UEL, 2001.

FROTA, S. Prosody and focus in European Portuguese. Phonological phrasing and intonation. New York: Garland Publishing, 2000.

LABOV, W. Principles of linguistic change. Internal factors. Cambridge, Blackwell, 1994. . Principles of linguistic change. Social Factors. Oxford, Blackwell, 2001.

MARCATO, F. Análise prosódica de preposições monossilábicas. 2013. 160 f. Dissertação (Mestrado em Estudos Linguísticos) - Instituto de Biociências, Letras e Ciências Exatas, Universidade Estadual Paulista, São José do Rio Preto, 2013.

MONARETTO, V. N. de O. Um reestudo da vibrante: análise variacionista e fonológica. 1997. 213 f. Tese (Doutorado em Letras). Faculdade de Letras, Pontifícia Universidade Católica do Rio Grande do Sul, Porto Alegre, 1997.

. O apagamento da vibrante pós-vocálica nas capitais do sul do Brasil. In: Letras de Hoje. Porto Alegre, v. 35, p. 275-284, 2000.

NESPOR, M.; VOGEL, I. Prosodic phonology. Prosodic phonology. Berlin: Mouton De Gruyter. Originalmente publicado em 1986 (Dordrecht: Foris), 2007.

SANKOFF, D.; TAGLIAMONTE, S.; SMITH, E. GoldVarb X: A variable rule application for Macintosh and Windows. Department of Linguistics, University of Toronto, 2005.

SANTANA, M. O R em coda silábica final nas três capitais do Sul do Brasil: Variação e Prosódia no corpus do ALiB. 2017. 116 f. Dissertação (Mestrado em Letras Vernáculas) Faculdade de Letras, Universidade Federal do Rio de Janeiro, Rio de Janeiro, 2017.

SERRA, C. Realização e percepção de fronteiras prosódicas no português do Brasil: fala espontânea e leitura. 2009. 241 f. Tese (Doutorado em Letras Vernáculas) - Faculdade de Letras, Universidade Federal do Rio de Janeiro, Rio de Janeiro, 2009.

SERRA, C. R.; CALLOU, D. M. I. A interrelação de fenômenos segmentais e prosódicos: confrontando três comunidades. XXVIII Encontro Nacional da Associação Portuguesa de Linguística. 1 ed. Coimbra: APL, v. 1, p. 585-594, 2013.

. Prosodic structure, prominence and / $\mathrm{r} /$-deletion in final coda position: Brazilian Portuguese and European Portuguese contrasted. In: Amedeo De Dominicis. (Org.). pS-prominenceS: Prominences in Linguistics International Conference. 1ed. Viterbo: DISUCOM PRESS, p. 96-113, 2015.

TENANI, L. E. Domínios prosódicos do português do Brasil: implicações para a prosódia e para a aplicação de processos fonológicos. 2002. $331 \mathrm{f}$. Tese (Doutorado em Linguística) Instituto de Estudos da Linguagem, Universidade Estadual de Campinas, 2002. 
. Domínios prosódicos e processos de reestruturação silábica. Estudos Linguísticos (São Paulo), São Paulo, v. 32, 2003.

. O bloqueio do sândi vocálico em PB e em PE: Evidências da Frase Fonológica. Organon (UFRGS), Porto Alegre, v. 18, n.36, p. 17-30, 2004.

VIGÁRIO, M. Prosodic structure between the Prosodic Word and the Phonological Phrase: recursive nodes or an independent domain? The Linguistic Review 27(4): 485530, 2010.

WEINREICH U.; LABOV, W.; HERZOG, M. Empirical Foundations for Theory of Language Change. In: Lehmann, Paul; Malkiel, Yakov. (eds.) Directions for Historical Linguistics. Austin: University of Texas Press. 95-188, 1968.

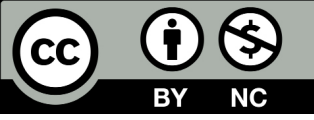

Data de submissão: 15/03/2018

Data de aceite: $19 / 11 / 2018$ 